\title{
An Economic Analysis of Groundnut Marketing - A Study
}

\author{
Leelavathi $\mathbf{R}$ \\ Assistant Professor, Department of Economics, Government Women's College, \\ Madakarinayaka Circle, Chitradurga, Karnataka, India
}

\begin{abstract}
Groundnut is one of the major commercial oil seed crop in India and world scenario. Groundnut which is also popularly known as peanut is one of the world's most popular and universal crops, cultivated in more than 100 countries of six continents. China and India are the largest producers of Groundnut. Although the USA was the third largest producer of Groundnut in the world during the mind 1990s, Nigeria became the third largest producer of Groundnut in the world as on 2002. Challakere is a backword taluk of Karnataka state. The present paper deals with to identify different agencies in the marketing of groundnut in APMC, Challakere, to study the problems faced by the farmers while marketing of groundnut and to study the viability of groundnut cropping in the study area. The paper shall be depended on primary and secondary sources of information.
\end{abstract}

Keywords: Climate, inadequate irrigation facilities, APMC, Labour

\section{INTRODUCTION:}

Groundnut is one of the major commercial oil seed crop in India and ranked first in area and second in production in the world with an area of 6.14 million hectare and production 7.40 million tones, India share is 22.08 per cent in world's area and 21.67 per cent in production of groundnut (2014-15). Groundnut, an important cash crop, is an annual pulse. Its seeds are a rich source of edible of protein (25.28). About two seeds of world production is crushed for oil and the remaining one third is consumed as food. Its cake is used as feed for making other food products and haulms provide quality fodder.

Climate conditions such as temperature and rainfall significantly influence the Groundnut production. Warm and moist conditions are very favorable than cool and wet climate, which results in slow germination and seedling emergence, increasing the risk of seed rot and seedling diseases.

Groundnut cultivation has increased from 6.8million hectare from 1980-81 to 8 million hectare in the recent year. Groundnut is mainly grown in five states, Andhra Pradesh, Gujarat, Tamil Nadu, Karnataka and Maharashtra and together they account for more than 90 percent of the crop's total area. The states Andhra Pradesh, Gujarat, account for more than half of the cultivated area. Andhra Pradesh, Gujarat state share 28 and 24 percent of the total groundnut area respectively in the country. Tamil Nadu and Karnataka share about 15 percent each of the total

Cultivated area about 8 percent of the total groundnut area in the country is in the state of Maharashtra. Among the major groundnut growing states, (Andhra Pradesh earns states of Tamil Nadu and Karnataka. Therefore the probable reasons for these fluctuations and variation in groundnut production are changes in relative prices of competing crops, as well as nonprice variables like productivity, varietals differences and rainfall. It is also badly affected by the weather conditions and inadequate irrigation facilities. Thus wide fluctuation in its acreage and variations in groundnut supply to the oil factories have always been a matter of concern and have recently assumed grave dimensions in India in general and in Maharashtra in particular. Although the Maharashtra state has a diversified cropping pattern in different regions depending upon agro-climatic conditions groundnut being an important cash crop grown in almost all the regions this crop has been purposively selected for the study

\section{Chitradurga District Scenario}

Chitradurga district is a backword distict of Karnataka state. Groundnut is a major agriculture crop in the 
district. Extensive damage to the Groundnut crop has directly affected mills in the district which are now faced with heavy losses. According to the agriculture department, over 80 percent of the Groundnut crop in the district has been destroyed by untimely rain. Of the 3.5 lakh hectares of cultivable land in Chitradurga district, Groundnut is grown on $1.5 \mathrm{~b}$ lakh hectares, making it a major crop, which is the backbone of nearly 70 oil mills. Fifty of them are located in Challakere taluk alone, which has the largest area under Groundnut in the district, at 81,490 hectares. Besides oil mills, the district has nearly 150 Groundnut shelling units, which together employ over 6000 people. Several others at the agricultural producing market committee (APMC) yard earn their livelihood when the crop is harvested. The Chellakere APMC alone has over 150 bullock cart owners, transport agencies and several hundred homilies who are largely dependent on the mills for survival, said K. Nagaraj, former president of the Chitradurga chamber of commerce. He said the mills employed workers from over 50 villages who earned Rs. 100 a day. He said the mills had an annual turnover of over Rs. 70 crore and they required nearly 14000 quintals of Groundnut to produce 600 tons of oil every day. But owing to the crop loss, production might come down to only 20 percent of this year.

\section{Importance of Groundnut}

Groundnut is one of the world's fifteen leading food crops and cultivated throughout the world. It is among the most important foods in international trade. Groundnut is popularly known as peanut in many countries though it is more a pea (a leguminous plant) than a nut. But it is considered as nut because of its high nutritional value. It is less expensive and nourishing food.

Groundnut is a cash crop and useful rotation crop.

$>$ It is easy to grow, withstands drought to some extent and so a choice crop for dry farming.

$>$ It is soil erosion resistant crop.

$>$ Being a legume crop it can fix atmospheric nitrogen. Thus maintains soil fertility.

$>$ All parts of this plant can be commercially used.

$>$ The plant stalks are fed to cattle in the form of green, dried and silage.

$>$ Groundnut shell, haulms and hay are good fodder. Groundnut cake is a good feed for livestock and it is also used as manure.

$>$ Groundnut is consumed in many ways and various forms:
$>$ Primarily used as a vegetable cooking oil.

$>$ Kernels are used directly as food or snacks for human consumption.

$>$ A large number of food products are prepared from groundnut -Boiled nuts, roasted nuts, salted nuts, groundnut milk, groundnut yogurt, groundnut bars, groundnut butter, groundnut cheese, bakery products etc

$>$ The groundnut is particularly valued for its protein content $(26 \%)$

\section{Review Literature}

A very brief review of studies on the subject has been made here under;

In a research paper on An Economics Analysis of Production and Marketing of Groundnut in Porbandar District of Gujarat by Ramjilal Choudhary, D. S. Rathore and Amod Sharma (2017), identified the compound growth rates of kharif groundnut area and production was negative and significant, while productivity was positive but nonsignificant. The per hectare cost of cultivation of kharif groundnut i.e. Cost ' $C$ ' was ' 50434.33 and it was 1.12B: C ratio.. The major items of cost of cultivation in kharif groundnut were rental value of land, hired human labour charges, seed, bullock labour charges and family human Labour. The functional analysis has indicated that 3 variables viz; human labour (X1), manures (X4), and phosphorus (X6) fertilizer in kharif groundnut are significant variables for which the output was responsive. The resource use efficiency kharif groundnut shows the resources will increase the output if used additional quantity. Per quintal cost of marketing of kharif groundnut was 389.22 and major items marketing cost of packaging charges, transport charges and commission charges were reported high. Nonavailability of labour and other inputs at peak period, high cost of key inputs low price to produce and lack of technical knowledge were the major constraints faced by cultivators in Kharif groundnut.

Vincent Kapopo and Maganga Assa (2012) in his research paper Economic Analysis of Groundnut Production in Kasungu District Malawi: A production Economics Approach he found that gross margin per Malawi Kwacha invested was. This means that the farmer returns MK2 for every kwacha invested. The Break Even Point (BEP) of production shows, at this level of cost of production, that farmers' minimum production is $147 \mathrm{Kg}$ per hectare 
for the farmer to break even. The farmer incurs MK95 for every $\mathrm{Kg}$ of groundnut produced. This means that the minimum price of groundnut, for the farmer just to recover the costs of production is MK95 per $\mathrm{kg}$ of groundnut. The foregoing analysis of production function indicates that farm size, seed and labor are the important factors of production that affect groundnut output in the study area. The regression coefficients of these inputs were positive and statistically significant. Farm size had the highest MVPs as compared to other inputs; however, this input is a fixed factor in the short run. Seed was the second production factor with higher MVP indicating that farmers can increase their groundnut output by using more seed.

A study carried out Keshav Prasad, Deepanshu Patel And Balwant Singh Sachan (2013) Economics of Production and Marketing of Groundnut in Block Behandar in District Hardoi (U.P.) he found that human labour and seed together accounted for the highest per cent share in the total cost of groundnut cultivation in the study area. The marketing channel of groundnut crop available with the farmers was 71.77 per cent of the unregulated market and the regulated market contributed only 28.22 per cent to the groundnut production. The percentage was higher due to the long process and formalities which took place in regulated market. The producer share in consumer's price was worked out at 81 per cent and 78 per cent in regulated and local/ unregulated markets, respectively. The higher producers share in regulated markets as compared to unregulated/local market was higher due to lower marketing cost, lower margin of profit and higher sale price.
Sugriv Kumar Maurya, RR Kushwaha, KK Mourya and Sarvesh Kumar (2017) Price Spread and Marketing Efficiency of Groundnut Marketing in Gorakhpur Districts of Eastern U.P, analyzed the marketing cost, marketing margin and price spread of groundnut marketing. The study was based on intensive enquiry of 100 farmers, winch selected randomly from 5 sampled villages in khorabar block of district Gorakhpur three marketing channel were the study found that producer consumer, producer whole seller-retailer consumer and producer village trader whole seller - retailer - consumer. Overall per farm marketed surplus was worked out 79.24 per cent. The producer s share in consumer rupee was worked out $97.89,83.13$ and 80.79 per cent in channel I, II and III respectively. The producer s share in consumer rupee was decreased with increase $m$ number of intermediaries.

\section{Objectives}

The following two are the objectives of the present paper.

1. To identify different agencies in the marketing of groundnut in APMC, Challakere

2. To study the problems faced by the farmers while marketing of groundnut.

3. To study the viability of groundnut cropping in the study area.

\section{The paper}

The present paper is descriptive and analytical in nature. For the purpose of analysis, both the secondary and primary data were being used. In the taluka of Challakere, in Chitradurga district, a total of 50 respondents, chosen randomly, were personally interview.

Table-01 Ages and Education Qualification Distribution of Respondents

\begin{tabular}{|c|c|c|c|c|}
\hline S.L No & Age & Percentage & Qualification & Percentage \\
\hline 1 & $18-30$ years & $11(22 \%)$ & Primary school & $14(28 \%)$ \\
\hline 2 & $30-40$ years & $15(30 \%)$ & High school & $16(32 \%)$ \\
\hline 3 & $40-50$ years & $13(26 \%)$ & Graduate of above & $10(20 \%)$ \\
\hline 4 & $50-60$ years & $08(16 \%)$ & Illiterate & $10(20 \%)$ \\
\hline 5 & Above 60 & $03(06 \%)$ & Total & $50(100 \%)$ \\
\hline & Total & $50(100 \%)$ & & \\
\hline
\end{tabular}

Source: filed survey 15.08.2018

The data presented shows the age of group of respondents out of the sample 50 respondents out of 22 per cent respondents between age group 18-35 years, 30 per cent respondents between age group 3040 years, 26 per cent respondents between age group 40-50years, 16 per cent respondents between age group 50-60 years and 06 per cent respondents between age group above 60 years; 28 per cent respondents having education level primary school, 24 percent of the respondents are having education 
International Journal of Trend in Scientific Research and Development (IJTSRD) ISSN: 2456-6470

level up to high school, 20 percent of the respondent are having education level up to graduate of above and the reaming 20 percent of the respondents in the study area are illiterates.

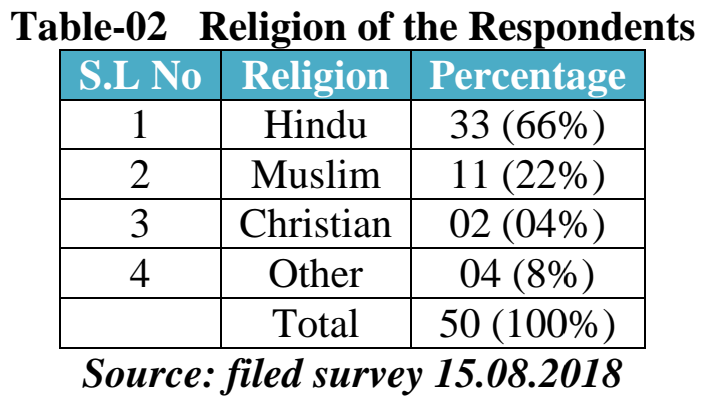

Table-02 shows that, religion of the respondents in the study area. Out 50 respondents 66 per cent respondents Hindus, 22 per cent respondents Muslim, 04 per cent respondents Christian and finally 08 per cent respondents other castes.

Table-03 Transportations vehicles by the Respondents

\begin{tabular}{|c|c|c|c|}
\hline $\begin{array}{c}\text { S. I. } \\
\text { No }\end{array}$ & $\begin{array}{c}\text { Transportatio } \\
\text { ns Vehicles }\end{array}$ & $\begin{array}{c}\text { No of } \\
\text { Respondent }\end{array}$ & Percentage \\
\hline 1 & Tiller & 8 & 16 \\
\hline 2 & Tractor & 10 & 20 \\
\hline 3 & Others & 14 & 28 \\
\hline 4 & Nil & 18 & 36 \\
\hline & Total & 50 & 100 \\
\hline
\end{tabular}

Source: filed survey 15.08 .2018

The data regarding the machines owned by respondents is shown in the above table. The table clearly shows that 16 per cent of respondents own tiller for cultivating groundnut cultivation, 20 per cent of respondents own tractor for cultivating groundnut, 28 per cent of respondents other and remaining 36 per cents of respondents do not have machines for cultivating groundnut cultivation.

Table-04 Problems Faced by the of Groundnut Crops Respondent

\begin{tabular}{|c|c|c|c|}
\hline $\begin{array}{c}\text { S. I. } \\
\text { No }\end{array}$ & $\begin{array}{c}\text { Problems faced } \\
\text { of groundnut } \\
\text { crops }\end{array}$ & $\begin{array}{c}\text { No of } \\
\text { Respondent }\end{array}$ & Percentage \\
\hline 1 & Labour & 15 & 30 \\
\hline 2 & Fertilizers & 11 & 22 \\
\hline 3 & Marketing & 6 & 12 \\
\hline 4 & Water & 18 & 26 \\
\hline Total & & 50 & 100 \\
\hline
\end{tabular}

Source: filed survey 15.08.2018
The above table labour the problem faced by the respondents while cultivation groundnut among of 50 interviewed respondent 30 percent of the respondents are facing labour problems, 22 percent of the respondents are fertilizer problem, 12 percent of the respondents are marketing problem and 18 percent respondents faced water problems.

Table-05 Land utilized for growing groundnut
crop of the respondents
\begin{tabular}{|c|c|c|c|}
\hline $\begin{array}{c}\text { S. I. } \\
\text { No }\end{array}$ & $\begin{array}{c}\text { Land } \\
\text { Utilized }\end{array}$ & $\begin{array}{c}\text { No of } \\
\text { Respondent }\end{array}$ & Percentage \\
\hline 1 & $\begin{array}{c}\text { Below } 2 \\
\text { acre }\end{array}$ & 04 & 08 \\
\hline 2 & $2-3$ acre & 14 & 28 \\
\hline 3 & $3-4$ acre & 24 & 48 \\
\hline 4 & $\begin{array}{c}\text { Above } 4 \\
\text { acre }\end{array}$ & 08 & 16 \\
\hline Total & & 50 & 100 \\
\hline
\end{tabular}

Source: filed survey 15.08.2018

Data shows that above the table 08 per cent respondents land use below 2 acres, 28 per cent respondents use of area less than 2-3 acres, 48 per cent respondents use of area less than 3-4 acres and 16 per cent respondents land use for growing groundnut crops above 4 acres.

Table 06 Category of Soil of the Respondents

\begin{tabular}{|c|c|c|c|}
\hline $\begin{array}{c}\text { S. I. } \\
\text { No }\end{array}$ & $\begin{array}{c}\text { Soil } \\
\text { category }\end{array}$ & $\begin{array}{c}\text { No of } \\
\text { Respondents }\end{array}$ & Percentage \\
\hline 1 & Black soil & 26 & 52 \\
\hline 2 & Red soil & 12 & 24 \\
\hline 3 & Sandy soil & 08 & 16 \\
\hline 4 & Alluvial soil & 04 & 08 \\
\hline Total & & 50 & 100 \\
\hline
\end{tabular}

Source: filed survey 15.08.2018

The details pertaining to the soil category of the respondents to cultivate groundnut crops is shown in table 06 It shows the 52 percent of the respondents opined that they are having black soil to cultivate groundnut, 24 percent of the respondents opined that they are having red soil to cultivate groundnut, 16 percent of the respondents opined that they are having Sandy soil to cultivate groundnut and 08 percent of the respondents opined that they are having Alluvial soil to cultivate groundnut in the study area. 
International Journal of Trend in Scientific Research and Development (IJTSRD) ISSN: 2456-6470

Table 07 Timing of Sales of The Producer Respondents

\begin{tabular}{|c|c|c|c|}
\hline $\begin{array}{c}\text { S. I. } \\
\text { No }\end{array}$ & $\begin{array}{c}\text { Timing of } \\
\text { Sales }\end{array}$ & $\begin{array}{c}\text { No of } \\
\text { Respondent }\end{array}$ & Percentage \\
\hline 1 & $\begin{array}{c}\text { Immediately } \\
\text { after sale }\end{array}$ & 10 & 20 \\
\hline 2 & Within 15 days & 14 & 28 \\
\hline 3 & $16-45$ days & 6 & 12 \\
\hline 4 & $\begin{array}{c}46 \text { days and } \\
\text { Above }\end{array}$ & 20 & 40 \\
\hline & Total & 50 & 100 \\
\hline
\end{tabular}

Source: filed survey 15.08.2018

As shown in table 07 that 20 per cent of the sample farmers reported that the payment was made soon after the sale of their groundnut produce, 28 per cent sell their produce with in 15,12 per cent of the respondents are selling their produce in lag of 16-45 days, and only 40 per cent of the respondent farmers are selling their produce in a time lag of 46 days and above.

\section{Table-08 Problems Faced By Beneficiary Farmers} in Availing the Services of Regulated Markets

\begin{tabular}{|l|c|c|}
\hline Type of Problem & $\begin{array}{c}\text { No of } \\
\text { Respondent }\end{array}$ & Percentage \\
\hline Low competition & 05 & 10 \\
\hline Problem of stay & 04 & 08 \\
\hline $\begin{array}{l}\text { Dominance of } \\
\text { homilies }\end{array}$ & 06 & 12 \\
\hline $\begin{array}{l}\text { Disputes with } \\
\text { traders }\end{array}$ & 08 & 16 \\
\hline $\begin{array}{l}\text { Grading is not } \\
\text { practiced }\end{array}$ & 02 & 04 \\
\hline No canteen facility & 04 & 08 \\
\hline Storage problem & 10 & 20 \\
\hline $\begin{array}{l}\text { Poor market } \\
\text { information }\end{array}$ & 11 & 22 \\
\hline Total & 50 & 100 \\
\hline
\end{tabular}

Source: filed survey 15.08.2018

From table 08 shows that it is clear that half of the sample beneficiary farmers reported that competition was less in the regulated markets for the trading of groundnut. Further, a few farmers especially the small and marginal farmers, who brought a small quantity of produce was given less importance by the traders. And therefore it fetched a lower price to them and 10 percent of sample beneficiary farmers complained about the dominating nature of homilies (paid workers) in the market. Though the homilies are expected to obtain license from Agricultural Market
Committees most of them seem to be the 223 supporters of traders. The sample beneficiary farmers reported that though the homilies are required to attend only to loading and unloading found performing other activities including weighment of the produce.

\section{Table -09 Source of Finance}

\begin{tabular}{|c|c|c|}
\hline Source of Finance & $\begin{array}{c}\text { No of } \\
\text { Respondent }\end{array}$ & Percentage \\
\hline Ownership Capital & 15 & 30 \\
\hline Loans & 15 & 30 \\
\hline others & 20 & 40 \\
\hline Total & 50 & 100 \\
\hline
\end{tabular}

Source: filed survey 15.08.2018

In the above table 09 shows that source of finance, in Groundnut marketing out of 50 members 30 per cent respondents ownership capital and 30 percent respondents source of finance loans and others , 40 per cent respondents were borrow of farmers is high source of income ownership capital most of the farmers were borrowing loans and other moneylenders.

\section{Suggestions}

The analysis of seasonal variation by prices and arrivals could be used by the farmers to market groundnut at the right time. The analysis disclosed that it is not profitable for farmers to store their produce after harvest. They could sell their produce immediately after harvest.

$>$ The analysis of seasonal variation by prices and arrivals could be used by the farmers to market groundnut at the right time. The analysis disclosed that it is not profitable for farmers for farmers to store their produce after harvest. They could sell their produce immediately after harvest.

Government should start diseases investigation centers with necessary grant to fulfill the purpose.

Farmers must be encouraged grow more and more profitable intercrops.

$>$ The APMC should maintain the necessary price and arrival data in a fixed for so that it could be used to make policy decisions. Daily market arrivals, sales and price should be recorded variety wise and quality wise.

$>$ The concerned authorities should make arrangement for scientific grading.

To impart specialized practical skill on processing, grading, marketing and marketing 
techniques in groundnut government can establish groundnut crops marketing training in state

$>$ The exploitation of producer by the large number of intermediaries could stop the income.

\section{Conclusion}

It may be said groundnut is an important commercial corps of India. It provides the essential good material for the some oil industries of the country. These oil industries provide employment about some oil mills to million people. The present study was therefore, designed to examine the whole system of marketing of groundnut in the taluk specifically to analyze the seasonal variations in market arrivals and prices the different channels in marketing groundnut from producers to oil industry owners, costs and contributions of various market intermediaries and to estimate the producers share in oil factory owner's rupee. Challakere taluk markets being the groundnut market of Challakere were selected for this study.

\section{References}

1. Gurumallappa, T.M., 1972, An economic analysis of marketing of groundnut in Raichur district. M.Sc. (Agri) Thesis (Unpublished), University of Agricultural Sciences, Bangalore.
2. Doddaiah, K., 1989, Economics of marketing and processing of groundnut in Raichur district, Karnataka. M.Sc.(Agri) Thesis (Unpublished), University of Agricultural Sciences, Bangalore.

3. Badami, V.K. (1936), Arachis hypogaea Linn. Groundnut or peanut-original habitat and its distribution in the world. Journal of Mysore Agriculture experiment Union, 15(14): 141-154.

4. Anonymous,(1941), Repot the marketing of groundouts in tide and Burma Manager of Publication, Delhi. Marketing Series in 28.

5. Sugriv Kumar Maurya, RR Kushwaha, KK Mourya and Sarvesh Kumar (2017) Price Spread and Marketing Efficiency of Groundnut Marketing in Gorakhpur Districts of Eastern U.P, Journal of Pharmacognosy and Phytochemistry 2017; 6(6): 712-715

6. https://www.krishimaratavahini.kar.nic.in/Markets /MarketProfile2.aspx? MrktCode=7

7. http://agriculture.anvayin.com/commodity/Ground nut/market/Challakere.htm 